\title{
On Deísmo. Another Case of Variation in Spanish Complementation
}

\section{Bruno Camus Bergareche}

Universidad de Castilla-La Mancha. Facultad de Letras

bruno.camus@uclm.es

\begin{abstract}
The present paper is dedicated to study the non-standard Spanish construction known as deismo. The construction can be defined as the use of the preposition $d e$ in front of subordinate infinite clauses like in the sentence No permito a mis hijos de llegar tarde 'I do not allow my children to be late'. The phenomenon appears in other standard variants of Romance languages but in contemporary Spanish this construction seems confined to some southern peninsular dialects. In this study we analyse this construction in conjunction with the data supplied by a group of speakers from Castilla-La Mancha and to a less extent the data obtained from other current dialects of Southern Spain and America. We finally attend to similar facts from Medieval and Classical Spanish and in Western Romance. By doing so we intend to provide the relevant historical clues for a proper account of this structure, as an example of variation in the Romance complementation system.
\end{abstract}

Keywords: syntax; infinitive clauses; complementizers; Romance complementation system; Castilla-La Mancha Spanish.

\section{Table of Contents}

1. Introduction 5. Deísmo: A Romance pattern

2. Deísmo in its context of infinitival complementation

3. An analysis of deísmo

6. Concluding remarks in Castilla-La Mancha Spanish References

\section{Deísmo in Contemporary and Old Spanish}




\section{Introduction}

The name deismo in contemporary Spanish grammars refers to some non-standard uses of the preposition de in front of embedded infinitive clauses as it is exemplified in the following sentences:

(1) a. Te pedí por favor de ser puntual.

2SG beg.PRES.1SG please of be.INF on time

'I begged you to please be on time.'

b. Me duele de no haberlo dicho a tiempo.

2SG hurt.PRES.3SG of not have.INF-3.N.AC say.PP on time

'I regret not having said it before.'

c. Me hicieron de reír.

1SG make.PAST.3PL of laugh.INF

'They made me laugh.'

d. Os vi de bajar del monte.

2PL see.PAST.1SG of come down.INF from-the mountain

'I saw you coming down the mountain.'

As these examples make clear, the preposition de, never present in these contexts in Standard Spanish, can precede infinitive clauses of different syntactic natures: in object position in (1a), in subject position in (1b), with causative construction in (1c) or after a perception verb in (1d).

Our objective is to describe these non-standard constructions as an example of variation in Spanish complementation, which is something that has been hardly noticed before. This construction can be paired with some other instances of variation also in this same area of the Spanish — and Romance - grammar, namely the ubiquitous dequeísmo, a much better known procedure that will serve as a reference throughout this presentation. The structure of the paper is as follows: section 2 will present the main facts and previous accounts of deismo in the general context of other prepositional infinitives and complementation in Spanish; in section 3 we will provide our analysis of this construction based on the data supplied by some Castilla-La Mancha speakers; next, in section 4 we will complete the account on Spanish deismo by adding other contemporary and ancient data; finally, in section 5 we will close the circle on deismo by interpreting it in the wider context of Romance languages; section 6 will then serve to summarize our arguments, as well as to present our conclusions. We will draw attention to the interesting and relevant question of the evolution of Romance complementation.

\section{Deísmo in its context}

\subsection{Embedded infinitive clauses in Spanish with preposition}

Often in Spanish — as in other Romance languages - non-finite clauses headed by infinitives are preceded by prepositions: 
(2) a. Me alegro de hacer lo correcto.

1SG happy.PRES.1SG of do.INF that right

'I am happy to do the right thing.'

b. Confío en llegar a tiempo.

trust.PRES.1SG in arrive.INF on time

'I hope to arrive on time.'

In the examples in (2) the infinitive clause is a PP complement subcategorized by the verb. Thus in (2a) alegrarse must be accompanied by a complement headed by de and confiar in ( $2 \mathrm{~b}$ ) by a complement headed by en. Of course the complements in (2) could also be a finite clause (3) or a simple noun phrase (4).

(3) a. Me alegro de que vengas.

$1 \mathrm{SG}$ be happy.PRES.1SG of that come.2SG

'I am happy that you are coming.'

b. Confío en que vengas.

trust.PRES. $1 \mathrm{SG}$ in that come.PRES.2SG

'I hope that you will come.'

(4) a. Me alegro de tu llegada.

1SG be happy.PRES.1SG of your arrival

'I am happy for your arrival.'

b. Confío en mi futuro.

trust.PRES.1SG in my future

'I am confident in my future.'

In Spanish these PP complements can never be cliticized and demand the presence of the stressed and non-clitic pronoun, as in (5). This is in contrast to other selected complements, like direct objects, which always admit a clitic substitute (lo when it is propositional), as in (6):
a. - ¿Te alegras
de que venga?
2SG be happy.PRES.2SG of that come.PRES.1SG

'Are you happy that I am coming?'
* -Sí, me lo alegro. /—Sí, me alegro
yes, 1SG 3.N.AC be happy.PRES.1SG yes 1SG be happy.PRES.1SG
de ello.
of it
'-Yes, I am happy about it.'

b. ¿Confías en mi futuro?

trust.PRES.2SG in my future

'Do you have confidence in my future?'
*-Sí, lo confío / - Sí, confío en ello.
yes 3.N.AC trust.PRES.1SG yes trust.PRES.1SG in it
'-Yes, I have confidence in it.'


(6)

¿Prometes venir? / ¿Prometes que vendrás?

promise.PRES.2SG come.INF promise.PRES.2SG that come.PRES.2SG

'Do you promise to come? / Do you promise that you will come?'

-Sí, lo prometo.

yes 3.N.AC promise.PRES.1SG

'-Yes, I promise.'

Nevertheless some transitive verbs — decir 'to say', mirar 'to look at' - sometimes select an embedded infinitive as their complement. This infinitive is preceded by $d e$ and can be cliticized by lo, as the rest of sentential direct objects:

(7)
a. ¿Te dijo
de ir al
cine?
2SG say.PAST.3SG of go.INF to-the cinema

'Did he tell you to go to the cinema?'

-Sí, me lo dijo.

yes 1SG 3.N.AC Say.PAST.3SG

'-Yes, he told me so.'

b. ¿Mirarás de averiguar esos datos?

have a look.FUT.2SG of find out.INF those figures

'Will you try to find out those figures?'

-Sí, lo miraré.

yes 3.N.AC have a look.FUT.1sG

'-Yes, I will try.'

These are special uses of decir and mirar whose meanings do not correspond to the canonical ones. Decir de + infinitive is 'to suggest, to propose' and mirar de + infinitive is 'to try'. Both of them are future-oriented verbs as Di Tullio (2011: 178) remarks. Nevertheless the facts stand the same; the $d e+$ infinitive clause is the object of the verb and the preposition is different from that in (2) since, as cliticization shows in (7), it does not head any PP selected by the preceding verb. On the contrary it resembles more the complementizer que 'that' in (8), with a finite clause instead of the infinitive of (7a):

¿Te dijo que fueras al cine?
2SG say.PAST.3SG that go.PAST.2SG to-the cinema
'Did he tell you that you should go to the cinema?'

-Sí, me lo dijo.
yes 1sG 3.N.AC say.PAST.3SG
'-Yes, he told me so.'

The actual connection between de in (7) and que can be clarified when we see that $d e$ can only appear if followed by an embedded clause. Otherwise there 
would be no preposition at all and we would be dealing with the regular Spanish transitive construction:
a. ¿Te dijo
$(*$ de) eso?
-Sí, me lo
dijo.
2SG say.PAST.3SG of
that
yes 1SG 3.N.AC say.PAST.3SG
'Did he tell you that?'
'-Yes, he told me so.'
b. ¿Mirarás
(*de) eso? - Sí, lo miraré.
have a look.FUT.2sG of that
'Will you try that?'
yes 3.N.AC have a look.FUT.1SG
'-Yes, I will try.'

\subsection{Deísmo as a non-standard feature. Previous accounts}

This Standard Spanish pattern with de + infinitive clause that appears in (7) for decir and mirar seems to behave similarly to the pattern used with many other verbs in Southern Spanish, particularly in Andalusia, Extremadura and Castilla-La Mancha, as we showed in (1). For instance, the following sentences, with a subordinate infinitive clause preceded by de, can be documented among the speakers from Ciudad Real, in Castilla-La Mancha: ${ }^{1}$
(10) a. No permito
a mis hijos de llegar tarde
not allow.PRES.1SG to my children of arrive.INF late
'I do not allow my children to be late.'
(Standard Spanish: No permito a mis hijos llegar tarde)
b. Estoy deseando de llegar a casa
be.PRES.1SG wish.GER of arrive.INF to home
'I am looking forward to getting home.'
(Standard Spanish: Estoy deseando llegar a casa)

As shown for each example, Standard Spanish equivalents of these two verbs permitir and desear typically lack any overt indication of complementation when followed by an embedded non-finite clause. The unexpected presence of the preposition de is actually the reason why this construction is referred to as deismo, following the name given by Gómez Torrego (1999: 2128-2129).

Current reference grammars of Spanish have not paid much attention to this construction. The first reference goes back to Zamora Vicente (1970: 330-331), who provides some Andalusian examples. It is also mentioned by Llorente Maldonado

1. Thanks should be given to the people who kindly contributed with crucial information on the use of deismo in Ciudad Real and other places of Castilla-La Mancha. They provided the data on which this paper has relied heavily. My colleague Jesús Barrajón and Luisa Abad Arias were my first respondents. Marta Blázquez interviewed some anonymous and most valuable speakers. Through her, we got in touch with Sonia Villa, from Retuerta del Bullaque (Ciudad Real), who became our best source in terms of speech and knowledge. Ana Rodado, Rosario García Huerta and Matías Barchino also gave interesting information on the matter. I am in debt to all of them for their enthusiastic contributions. 
(1980: 36) for the first time in connection with the so-called dequeismo, which consists of the insertion of the same preposition de before que in the subordination of finite clauses in non-Standard Spanish:
Pienso
de que haces
lo correcto.
think.PRES.1SG of that do.PRES.2SG that right
'I think that you are doing the right thing.'
(Standard Spanish: Pienso que haces lo correcto)

The same explanation appears in later studies such as Náñez (1984: 239-241), Gómez Torrego (1999), already mentioned above, RAE/ASALE (2009: § 43.6u) and Perea Siller (2008). These last three works deserved to be mentioned for their interesting contribution to the presence of the $d e+$ infinitive construction in Medieval and Classical Spanish that had never been previously noted.

Recent authors have addressed the deismo within a broader perspective. This is the case of Di Tullio (2011), who goes beyond the relation with dequeismo and considers the whole scenario of complementation in Spanish and the nature of de in these constructions in comparison with $d e$ in the subcategorized PPs of sentences like (1)-(4) above, along the lines we have discussed. The contribution of Pato and de Benito Moreno (2012) is somehow different because it is mostly focused on defining the current dialectal extension of deísmo. After clearly establishing its regular presence in Southern Peninsular Spanish, the study of Pato and de Benito Moreno (2012) adopts an autonomous view of deismo and describes carefully how this use is distributed within syntactic and semantic constraints. Taking these two later accounts as a point of departure, we will try a finer analysis of deismo structures found in Castilla-La Mancha in the following section, before we address the rest of contemporary and historical samples of deismo in Spanish.

\section{An analysis of deismo in Castilla-La Mancha Spanish}

\subsection{De as an overt complementizer for infinitive clauses}

As suggested above, we will consider from now on that the element de - both in the standard sentences of (7) and in those used in Ciudad Real of (10) - is not a real preposition and thus, it does not head any PP clause. The de of deismo structures must be considered, as Di Tullio (2011: 178-180) claims, an overt realization of the COMP node that heads the embedded infinitive clause. We already saw in (7) and (9) that these infinitive clauses represent true objects and are regularly cliticized by means of $l o$, a form that never pronominalizes a PP in Spanish. The sentences in (8) showed that they are equivalent to typical object subordinate finite sentences introduced by the complementizer que.

Another evidence against the prepositional nature of de in deismo structures is offered by its behaviour in pseudo-cleft sentences, a test first suggested by Demonte and Fernández Soriano (2005) with respect to de in dequeismo. The fronted phrase must include $d e$ if it refers to a real PP (12) but, if it corresponds to an infinitive clause with deismo, it does not include it (13): 
(12) De lo primero que me alegro es de hacer lo correcto. of the first that 1SG be happy.PRES.1SG is of do.INF that correct 'The first thing that makes me happy is doing the right thing.'

(13) a. Lo primero que dije es de ir al cine. the first that say.PAST.1sG is of go.INF to-the cinema 'The first thing I suggested is to go to the cinema.'

b. Lo primero que no permito a mis hijos es de llegar the first that not allow.PRES.1SG to my children is of arrive.INF tarde.

late

'The first thing I do not allow my children is to be late.'

There are still more data that clearly support this consideration of de in deismo sentences as a complementizer and not as part of a PP. For instance, Ciudad Real Spanish extends the use of deismo beyond object infinitives, as in (10) above, to subject infinitives, as in (15) below. According to standard assumptions, a PP is not expected in subject position. Actually deismo is particularly productive in this structure with so-called pseudo-impersonal verbs of psychological affection such as apetecer 'to feel like', pesar or doler 'to regret' or the verbal phrases with the light verb dar 'give' (pena 'sorrow' / lástima 'pity' / vergüenza 'shame' / asco 'repugnance' / reparo 'qualm' / miedo 'fear' / pánico 'panic', etc.). All these forms display a structure with a dative internal argument and a subject that can be realized by a DP in agreement with the main verb, as in (14), but also by a finite or non-finite clause. In this last case the infinitive is regularly preceded by de in deismo dialects, as shown in (15).

(14) a. Me duelen sus desplantes. 1SG hurt.PRES.3PL their rudeness.PL 'Their rudeness hurts me.'

b. Me dan vergüenza esos amigos. $1 \mathrm{SG}$ give.PRES.3PL shame those friends 'I am ashamed of those friends.'

(15) a. Me duele de no haberlo dicho a tiempo. 1SG hurt.PRES.3SG of not have.INF-3.N.AC say.PP on time 'I regret not having said it before.'

b. Le da vergüenza de gastar ese dinero. 3.DAT give.PRES.3SG shame of spend.INF that money 'He/she is ashamed to spend that money.'

The infinitive clauses in (15) cannot be the complement of any PP clause headed by de since no PP could be in the position of subject of duele and da vergüenza. Instead they are the complement of the $\mathrm{CP}$ headed by de which stands properly as 
a sentential subject of these pseudo-impersonal structures, just in the same way a finite clause headed by que can also be their subject:
(16) a. Me duele
que no lo dijeras
antes.
1SG hurt.PRES.3SG that not 3.N.AC say.PAST.2SG before
'I regret that you did not say it before.'
b. Le da
vergüenza que gastes
ese dinero.
3.DAT give.PRES.3SG shame that spend.PRES.2SG that money
'He/she is ashamed that you are spending that money.'

Finally, if $d e$ is the complementizer of an infinitive clause, we would expect it to remain together with its complement whenever we move the embedded sentence. And that is what actually happens, for instance, in cases of fronting - topicalization or contrastive focus as in (17) - or if it appears dislocated in the right margin of the sentence, as in (18):

(17) a. ¿Verdad que no les permites a tus hijos de llegar true that not 3.PL.DAT allow.PRES.2SG to your children of arrive.INF tarde?

late

-Eso es, de llegar tarde no se lo permito.

that is of arrive.INF late not 3.DAT 3.N.AC allow.PRES.1SG

'You don't allow them to be late, do you? - That's true, that I don't allow it to them.'

b. De gastar ese dinero le da vergüenza, no de

of spend.INF that money 3.DAT give.PRES.3SG shame not of tenerlo.

have.INF-3.M.AC

'It's spending that money that embarrasses him, not to have it.'

(18) Esto mismo no permito, de llegar tarde.

this self not allow.PRES.1SG of arrive.INF late

'This I don't allow, to be late.'

\subsection{Distribution of deísmo in Ciudad Real}

The definition of de as a complementizer in the deismo contexts forces us to put it in relation with the complementizer que in finite clauses. Nonetheless, as Di Tullio (2011: 181-182) already noticed, there is an important difference between them and it relies on the strongly restricted distribution of $d e$, both syntactically and semantically. We try through all this section to determine this limited extension of deismo in order to explain its nature using the examples supplied by Ciudad Real speakers of Castilla-La Mancha Spanish. ${ }^{2}$

2. All the examples representing Ciudad Real speech correspond to speakers from this province previously mentioned in footnote 1 . 
But before, we will open a parenthesis and consider the relation of deismo with the complementizer de que, a non-standard variant of que, and the so-called dequeis$m o$, already cited as a source or parallel development of deísmo. As we will see later in the study, the data do not fit the expectation that there is a causal and straight relationship between these two types of complementizers in contemporary non-Standard Spanish. Actually, the Ciudad Real speakers who normally insert $d e$ in the relevant non-finite embedded contexts never present dequeísmo - or de in finite embedded clauses - Moreover prototypical dequeista sentences are clearly rejected in favour of those coincident with Standard Spanish, as illustrated in the following example:

(19) Creo

$(*$ de) que iré.

think.PRES.1SG of that go.FUT.1SG

'I think that I will go.'

Furthermore, these speakers consistently enough prefer the que solution instead of the de que one in those contexts where the preposition is selected by the main verb (cf. above (3a)). For instance, a sentence like (20) below is what they produce for embedded clauses with acordarse 'to remember' as the main verb, which selects complements headed by de (thus de que) in Standard Spanish:

(20) Me acuerdo

que no fuiste

al colegio.

1SG remember.PRES.1SG that not go.PAST.2SG to-the school

'I remember you did not go to school.'

This alternative procedure, called queismo, which turns a simple que into the only actual complementizer in completive sentences, is in fact very common in Ciudad Real and Castilla-La Mancha, as the ALECMan shows (map SIN14-ANTES (DE) QUE AMANEZCA).

Apart from this first remark, some additional comments on the stylistic and social status of this dialect may be needed. In Ciudad Real deísmo constructions are well known by all kinds of speakers but they are strongly stigmatized. This means that, unless they can be occasionally heard among learned individuals, they are usually found only in the everyday speech of uneducated people. It is therefore more documented in rural areas. This contributes to the assumption in urban and educated settings that deismo is an unequivocal feature of paleto or peasant speech. Nevertheless, the phenomenon is often unobserved as most speakers do not pay any attention to it. It is therefore hardly ever noticed and corrected. This is explained partially due to the lack of explicit prescriptions on the matter in schools and media. This general disdain contributes to the unconsciousness of the deismo speakers. Such unawareness consequently renders them very insecure about these constructions and permeable to standard or non-deismo grammar. The result is a considerable instability and dispersion in the usage of $d e+$ infinitive clauses in Ciudad Real and all the deismo areas in Castilla-La Mancha. ${ }^{3}$

3. The ALECMan (García Mouton and Moreno Fernández 2003) - the linguistic atlas of this regionclearly shows a significant presence of the construction. In the section dedicated to syntax, there 
Keeping in mind this last difficulty, we shall now consider the preferred contexts for deísmo in terms of syntactic and semantic considerations. As we could see in previous examples of deísmo — sentences in (10) and (15) above-, the infinitive clauses under control verbs are the first locus where the complementizer de can be found in Ciudad Real Spanish. We find infinitive clauses with de in object position with a subject controller for verbs like intentar 'to try', aceptar 'to accept', lamentar 'to regret' and desear 'to wish', a verb already mentioned in (10b), as in the following sentences:

(21) a. Intenta de tirar con esta escopeta.

try.IMP of shoot.INF with this shotgun

'Try to shoot with this shotgun.'

b. Juan lamenta de no haber ido al cine más Juan regret.PRES.3SG of not have.INF go.PP to-the cinema more a menudo.

often

'Juan regrets not having gone to the cinema more often.'

We also have sometimes $d e+$ infinitives in object position with an object (dative) controller, as in (10a) above, with verbs like prohibir 'to forbid', proponer 'to suggest' or pedir 'to ask to':

(22) a. Le prohibieron de seguir escuchando.

3.DAT forbid.PAST.3PL of continue.INF listen.GER

'They forbade him/her to carry on listening.'

b. Ayer os pedí de ser puntuales.

yesterday 2SG ask.PAST.1SG of be.INF on time

'Yesterday I asked you to be on time.'

But we also find infinitive clauses in subject position with dative controllers with different types of pseudo-impersonal verbs like apetecer 'to feel like', pesar 'to regret' and, as we have already seen in (15), doler 'to hurt, to regret' or dar 'to give' plus a noun such as pena 'sorrow' / lástima 'pity' / vergüenza 'shame' / asco 'repugnance' / reparo 'qualm' / miedo 'fear' / pánico 'panic' ..., as in (23). The same syntactic description corresponds to the group of typical impersonal constructions with copulative ser 'to be' like ser necesario 'to be necessary' / ser costumbre 'to be customary' / ser una lástima 'to be a pity', etc. or other verbs like tocar 'to be one's turn', corresponder 'to correspond', interesar 'to interest', costar 'to be hard', ocurrir 'to happen', shown in (24):

are three maps that explicitly cover deísmo: SIN-88 DEJAR (DE) SALIR, SIN-89 HACER (DE) REÍR and SIN-98 NO LO OÍ (SENTÍ) (DE) VENIR. We come across this feature all over Castilla-La Mancha with the exception of the easternmost area of the provinces of Guadalajara, Cuenca and Albacete. It is actually the province of Ciudad Real the main stronghold of this non-standard feature. 
(23) Hoy me apetece de salir. today 1SG feel like.PRES.3SG of go out.INF 'Today I feel like going out.'

(24) a. Aquí es costumbre de comer temprano. here is habit of have lunch.INF early 'It is customary here to have lunch early.'

b. Os toca de fregar.

2SG be one's turn.PRES.3SG of do the dishes.INF 'It is your turn to do the dishes.'

Inside this group of infinitive clauses under control verbs, deísmo structures do not seem to be limited by syntactic considerations. They do not depend on the position of the embedded clause, it can be object, subject or even an attribute (12)-(13), nor on the kind of controller, subject or object, of the main clause. But, on the contrary, some preferences from a semantic point of view can be noticed. It seems very clear that, as far as Ciudad Real dialect is concerned, psychological verbs of affection are often accompanied by this complementizer de: apetecer 'to feel like', doler 'to hurt', pesar and lamentar 'to regret', dar 'to give' with pena 'sorrow' / lástima 'pity' / vergüenza 'shame' / asco 'repugnance' / reparo 'qualm' / miedo 'fear' / pánico 'panic' ..., ser una lástima 'to be a pity', costar 'to be hard' ... In addition to this semantic class we find other classes not as well represented. These include some verbs of intention (intentar 'to try'), verbs of influence (pedir 'to ask to', proponer 'to suggest', prohibir 'to forbid'), a few verbs of speech or assertion (decir, which accompanied by de corresponds rather to a conative verb 'to suggest', and aceptar 'to accept'), some verbal phrases with ser 'to be' with a modal content like ser necesario / improbable / fácil 'to be necessary / improbable / easy' ..., and, finally, one verb of will, desear 'to wish'. Curiously enough this form accepts $d e+$ infinitive only in the punctual periphrasis estar deseando, which is closer to psychological verbs such as apetecer. As the Spanish-American samples on deismo from Di Tullio (2011: 181) show, the verbs of communication, speech or thought, which are common in dequeista contexts, are not included. But, contrary to these same data of Di Tullio (2011: 178), Ciudad Real or Castilla-La Mancha deísmo is not constrained by the temporal interpretation of the infinitive clause. It is true that, as in SpanishAmerican sentences, they have often a future or prospective reading, for instance with the verbs of intention or influence or with decir. But, otherwise, they can also be past-oriented, as it is the case with doler 'to hurt', pesar and lamentar 'to regret', that easily admit the compound or perfect form of an infinitive (haber + participle), as in (21b) above.

These latter considerations favour a definition of the complementizer $d e$ in Castilla-La Mancha Spanish as a form with no semantic content. Its lack of any relevant meaning distinguishes this de from the de that appears in dequeísmo, which, according to Demonte and Fernández Soriano (2001, 2005, 2009), provides an evidential content typical of the clauses where it is found. For instance, 
it can be found under communication and speech verbs, that is, in epistemic contexts. ${ }^{4}$

This hypothesis of a meaningless or empty complementizer de does not only match the data presented so far but also other data. In Ciudad Real the deísmo does not appear at all with many verbs that are similar in meaning to some of those just presented as usually selecting $d e$. For instance, inside the group of psychological verbs of affection, there are some verbs of high frequency that seem to never be accompanied by de + infinitive. This is the case for gustar 'to like' or encantar 'to love' among those that are part of the pseudo-impersonal verbs with a postposed subject (the infinitive clause, in this case) and a dative controller. Other verbs close to this group but belonging to the class of subject control verbs, like preferir 'to prefer' or odiar 'to hate', do not seem to induce deísmo in Ciudad Real.

Among the classes with only a few representatives with deismo, the Standard Spanish structure with no de is consequently more common. A verb of intention like probar 'to try', unlike intentar, is very seldom followed by de. Pensar 'to think', a verb of thought or opinion, follows in Ciudad Real the standard construction with a direct object or a prepositional object with en, but never with de. The same preferences hold for prometer 'to promise' and a group of verbs of modal interpretation like esperar 'to hope', a subject control verb, or convenir 'to be advisable' and hacer falta 'to be necessary', again among pseudo-impersonal or impersonal verbs with a dative controller.

It is certainly plausible that stylistics and the sociolinguistic situation may play some role in this somewhat capricious split between deísmo and non-deísmo contexts in Castilla-La Mancha Spanish. Whether or not this is true, this split suggests a kind of lexical selection at least for these syntactic and semantic groups of verbs. The triggering of the presence of an empty instead of an overt (de) complementizer with a subordinate infinitive seems to depend on each lexical entry. In this regard, every control verb within the preceding semantic classes should be marked in the lexicon as a non-de verb or a de verb.

This condition does not materialise in the case of another group of verbs which systematically reject this de complementation with infinitives among Ciudad Real speakers. It is the verb class formed by typical modal verbs like poder 'to be able, can', querer 'to want', or necesitar 'to need'. In Spanish reference grammars their combination with an infinitive is considered a modal periphrasis or verbal phrase. Hence the infinitive cannot be considered part of a clause in the position of a subcategorized argument, an object, of the main verb. There is no subordination between the inflected modal verb and the infinitive, whose actual relation is the one we find between an auxiliary and a main verb. Therefore, no complementizer position is needed and no de is required. As we

4. As claimed in Demonte and Fernández Soriano (2009: 24), de que could be considered a complex complementizer with two heads where the first one de encodes Mood/Evidentiality features and que stands for the rest. In Standard Spanish, on the contrary, all these features are amalgamated under the simple complementizer que. The same idea of a de carrying evidentiality features inside a de que complex for dequeísmo dialects is defended in Del Moral (2008). 
mentioned above, that is what actually happens. Even more, in Ciudad Real no other Spanish periphrasis or verbal group formed by the adjunction of an infinitive to an inflected (auxiliary) verb seems to accept deismo. Thus, in this speech the habitual periphrasis with soler or acostumbrar 'to be used to', is never followed by de, unless its meaning is close to the deismo structure formed, by the verb phrase ser costumbre 'to be costumary'.

\subsection{Perception and causative verbs and deísmo in Ciudad Real}

If the syntactic structure happens to be relevant to the presence of deismo in the case of periphrasis, we would expect it not to appear when the relation between an inflected verb and an infinitive is not as easily described as the one we find with control verbs, that is, the one corresponding to a verb with a sentential argument. But in the dialect we are describing, there are two structures that induce deismo in a consistent manner. They are the so-called infinitives with subject in accusative after perception and causative verbs, a structure often considered to be half way between periphrasis and subordination (Hernanz 1999: 2236-2265).

Actually, among Ciudad Real and Castilla-La Mancha speakers the infinitive clause under these two kinds of verbs is considered one of the most conspicuous contexts for deismo. Therefore we can easily come across sentences like the ones that follow, all of them without de in Standard Spanish:

(25) a. Sentí a tus amigas de llegar por la mañana. hear.PAST.1SG to your friends of arrive.INF in the morning 'I heard your friends arrive in the morning.'
b. Ayer te vi
de bailar.
yesterday 2SG.AC see.PAST.1SG of dance.INF
'Yesterday I saw you dance.'
(26) No hagas de rabiar a tu hermana. not make.SUBJ.2SG of be furious.INF to your sister 'Don't make your sister mad.'

In (25) we have two verbs of perception whose complement is a constituent formed by the infinitive clause and a phrase in accusative. This corresponds to the subject of the infinitive but receives case from the main verb. The pronominalization of the embedded clauses of those examples - lo senti (*a tus amigas) and (*te) lo $v i$ - , with only one possible object in accusative, shows, first, that both the accusative and the infinitive clause are part of the same constituent. And, second, that the complement in accusative is not an argument of the main verb but of the infinitive as its subject. The following sentences in (27) are versions of (25) with a finite completive instead of a non-finite infinitive clause. They let us discover the structure we have just described: 
(27) a. Sentí que tus amigas llegaban por la mañana.

hear.PAST.1SG that your friends arrive.PAST.3PL in the morning

b. Ayer vi que bailabas.

yesterday see.PAST.1SG that dance.PAST.2SG

It should be added in order to confirm the structural identity of these sentences that the pronominalization of (27) is equal to the one in (25), that is, lo senti and lo $v i$, where the clitic lo corresponds to the whole subordinate clause.

As for the causative example with hacer 'to make, to do' in (26), the same analysis would apply. The infinitive and the subject in accusative are also part of the same constituent. These can be substituted by just one pronoun or one finite que clause: No lo hagas (*a tu hermana) / no hagas que tu hermana rabie. As it is the case with perception verbs, the causative hacer seems then to select only one internal argument, but this must be formed by a clause, either a non-finite - an infinitive clause-, or a finite one - a canonical completive clause with que- It is not surprising then that the infinitive clauses selected by perception and causative verbs incorporate a complementizer de in deísmo dialects, as shown in (25) - (26).

Some issues take place when we consider some other features typical of these 'infinitive with accusative' sentences described, for example, in Hernanz (1999: 2555-2558). First, it is possible in Standard Spanish to have a clitic corresponding to the complement of the infinitive in a preverbal position adjacent to the main verb:

(27) a. Te vi comer la carne/Te la vi comer. 2SG see.PAST.1SG eat.INF the meat 2SG 3.F.AC see.PAST.SG eat.INF 'I saw you eating the meat / I saw you eating it.'

b. Te hice traer la maleta / Te la hice 2SG make.PAST.1SG bring.INF the suitcase 2SG 3.F.AC make.PAST.1SG traer.

bring.INF

'I made you bring the suitcase / I made you bring it.'

This is exactly what happens when the main verb is the auxiliary of a periphrasis and hence there is no complementation between this form and the infinitive:

(28) a. Quiero / suelo traer la maleta.

Want.PRES.1SG am used bring.INF the suitcase

'I want / am used to bring the suitcase.'

b. La quiero / suelo traer.

3.F.AC want.PRES.1SG am used bring.INF

'I want / am used to bring it.'

That is not the only peculiarity regarding these constructions. There are still some others that suggest a certain affinity with the syntax of a verbal group or a 
periphrasis. For instance, the speakers seem to prefer to have the accusative subject of the infinitive to the right of the infinitive (29a) rather than to the right of the main verb (29b). Thus adjacency between both verbal forms is preserved, as is usual with periphrasis:
a Vi thice la maleta a Juan. see.PAST.1SG make.PAST.1SG bring.INF the suitcase to Juan
b. Vi / hice
a Juan traer la maleta. see.PAST.1SG make.PAST.1SG to Juan bring.INF the suitcase 'I saw Juan bringing the suitcase / I made bring the suitcase to Juan.'

In addition, as shown by the gloss of (27b), in Standard Spanish the causative construction may present a dative, which is the subject of the infinitive, and another complement in accusative, as in (30). This would make possible an analysis of the combination hacer + infinitive as a periphrasis with two different internal arguments, one in dative and the other one in accusative.
(30) a. Hice
traer la maleta a Juan.
make.PAST.1SG bring.INF the suitcase to Juan
'I made bring the suitcase to Juan.'
b. Se la hice traer.
3.DAT 3.F.AC make.PAST.1SG bring.INF
'I made bring it to him.'

These traits, and particularly the fronting of the pronoun in (27), favour a noncomplementation analysis of the combination formed by perception or causative verb and infinitive. Apparently, this would pose difficulties in deismo dialects to consider de as a complementizer. However, the behaviour of deísmo speakers in Ciudad Real shows that this later solution can still be maintained as long as fronting and $d e$ are not compatible for them. When they are forced to put the complement of the infinitive to the left of the main verb, they would only accept the standard solution without de (31). Moreover, they would reject clitic fronting for their usual deísmo sentences with these verbs (31b):
(31) $\mathrm{Te}$
la vi
/ hice
$(*$ de) traer.
2SG.DAT ${ }^{5}$ 3.F.AC see.PAST.1SG make.PAST.1SG of bring.INF
'I saw you bringing it / I made you bring it.'
5. As explained above and seen in (30), when the internal argument in accusative of the infinitive is fronted next to the main verb, the original external argument in accusative must become a dative, in order to avoid an interpretation where ver / hacer would select two different arguments in accusa- tive.




$$
\begin{aligned}
& \text { a. * Te la vi / hice de traer. } \\
& \text { 2SG.DAT 3.F.AC see.PAST.1SG make.PAST.1SG of bring.INF } \\
& \text { b. Te vi / hice de traerla. } \\
& \text { 2SG.AC/DAT }{ }^{6} \text { see.PAST.1SG make.PAST.1SG of bring.INF-3.F.AC } \\
& \text { 'I see you bringing it / I made you bring it.' }
\end{aligned}
$$

These examples lead us to conclude that the presence of de necessarily implies a complementation analysis, at least with reference to the pair in (31). Consequently, it confirms the definition so far suggested for this element de preceding infinitives.

We want to end up this section by reminding that other semi-causative verbs, which not always behave syntactically like hacer, also tend to induce deismo in Ciudad Real. This is the case of dejar 'to let' or mandar 'to order', which are half way between causative and conative / influence verbs already mentioned (such as prohibir 'to forbid', decir (de) 'to suggest' or even pedir 'to ask for'). This causative / conative meaning seems to be therefore another appropriate environment for the deismo type of complementation.

\section{Deísmo in Contemporary and Old Spanish}

\subsection{Deísmo in America and Southern Spain}

The pattern of deismo found in Castilla-La Mancha Spanish, limited to some control verbs and the "infinitive with subject in accusative" structures, is not the only one in Contemporary Spanish. For instance, Di Tullio (2011) recognises different possibilities among Spanish-American uses of a complementizer de. There is first an optional element that appears with verbs of intention, influence, will ..., that corresponds roughly to non-standard de in Castilla-La Mancha and Peninsular Spanish. Di Tullio also discusses another use of de of a mandatory nature with the verb decir, which is the same we considered at the beginning of this work as a sample of de complementation in Standard Spanish (7a). According to her, this mandatory de is not semantically empty and incorporates a prospective content and some constraints on the interpretation of its subject. Nonetheless, these semantic traits can be incorporated in the consideration of the previous facultative de since this one does not violate it in American dialects. This de would simply remain semantically unspecified. On the contrary, Ciudad Real deísmo does not seem to be circumscribed to any type of semantic requirement on the part of the main verb, as we saw in section 2.2. And finally there exists another de which alternates with other prepositions as the head of PPs selected by verbs such as quedar (en / de) 'to agree', or pensar (en / de) 'to think of'. It should be said that this can also be found in Peninsular Spanish, as we will see immediately, but apparently not in Ciudad Real.

6. In this structure, with the internal argument of an embedded transitive verb (traer) next to it at the end, the clitic that corresponds to its subject is accusative with a perception verb (ver) but dative with causative hacer. 
A more detailed and extensive version of deismo is found in other Southern Spanish dialects, according to the data provided both by Pato and De Benito Moreno (2012) and the COSER surveys. ${ }^{7}$ As their findings show and previous accounts had so far claimed, $d e+$ infinitive structures can be found almost in every province of the regions of Andalusia and Extremadura. In addition, it must be said that, beyond this preferred southern distribution, the procedure can also be documented less spontaneously in other places of Spain such as Madrid, Zamora or even Catalonia. If we concentrate on the situation in Andalusia and Extremadura, the scenario portrayed by these studies is different from the one we have described for Castilla-La Mancha in at least two relevant aspects. Firstly, the presence of de seems to be more extended in control contexts and, therefore, we find it attached to more verbs, most of them perfectly discarded in Ciudad Real. For instance, we find deísmo with pseudo-impersonal and impersonal verbs (33) and psychological verbs, such as gustar or encantar (34), that are hardly ever found in Castilla-La Mancha:

$$
\begin{aligned}
& \text { a. ... le convenía } \\
& \text { 3.DAT be advisable.PRES.3SG of have.INF } \\
& \text { '... it suits him/her to have ...' [Gil Márquez (COSER HU2114)] } \\
& \text { b. ... te haría falta de sacárselo } \\
& \text { 2SG need.COND.3SG of get out.INF-3.M.AC } \\
& \text { '... you would need to get it out' }
\end{aligned}
$$

[Jimena de la Frontera (COSER HU1109)]

(34) a. ... me gustaba de ir con ella

1SG like.PAST.3SG of go.INF with her

'... I liked going out with her'

[Orellana de la Sierra (COSER BA723)]

$$
\begin{aligned}
& \text { b. ... me encantó de escucharla } \\
& 1 \mathrm{SG} \text { love.PAST.3SG of listen.INF-3.F.AC } \\
& \text { '... I loved to listen to her' }
\end{aligned}
$$

And secondly, this wider extension includes in both regions the insertion of $d e$ before the infinitives of Standard Spanish periphrasis such as soler and combinations with prototypical modal verbs as poder 'can' or querer 'want':

7. Special thanks should be given to Inés Fernández Ordóñez, Enrique Pato and particularly Carlota de Benito for allowing us open access to the COSER surveys (Fernández Ordóñez, dir., 2005-) and for helping with the information and data concerning deismo. Most of the data presented below were previously collected and classified by Carlota de Benito and were kindly provided to us by herself and the COSER searchers in the Universidad Autónoma de Madrid. 


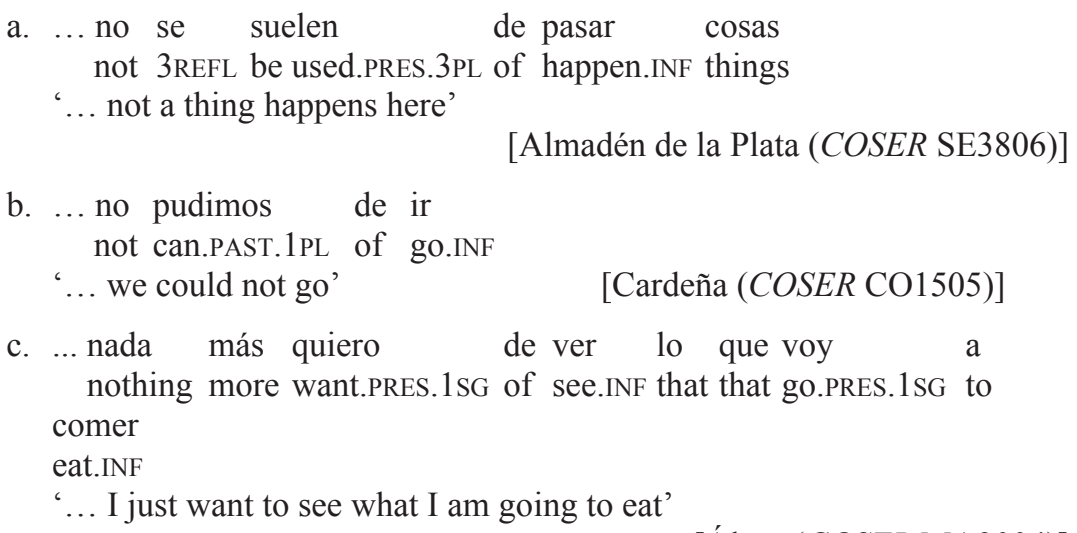

[Álora (COSER MA3004)]

If we want to maintain, as it is generally accepted, that these combinations correspond to a verb group and, therefore, the infinitive is not part of any embedded clause subcategorized by the inflected verb, the presence of de cannot be explained at all as a complementizer. This argument then poses serious problems to the analysis so far defended for deismo, unless we could provide an independent explanation for the sentences in (35). And indeed, this might be done if we relate the insertion of $d e$ here with the preposition usually found between auxiliaries and verbs in other Spanish verb complexes and periphrasis (García Fernández 2006). For instance, we have deontic (modal) deber de + infinitive, haber de + infinitive, terminative acabar de + infinitive or venir de + infinitive. Moreover, some other prepositions can still be found, for example, $a$ (ir $a+$ infinitive, empezar $a+$ infinitive, romper $a+$ infinitive) or por (estar por + infinitive). Interestingly enough, some sentences from COSER in Andalusia and Extremadura seem to suggest the extension of this type of preposition to other periphrasis. We find, for instance, venir de + gerund and ir de + gerund instead of venir + gerund and $i r+$ gerund, both of them regular continuative periphrasis in Standard Spanish:

$$
\begin{aligned}
& \text { a. ... viene de haciendo una encuesta } \\
& \text { come.PRES.3SG of do.GER a survey } \\
& \text { '... he/she is conducting a survey' }
\end{aligned}
$$

[Bélmez de la Moraleda (COSER JA 2302)]

$$
\begin{aligned}
& \text { b. ... cuando íbamos de navegando } \\
& \text { when go.PAST.1PL of sail.GER } \\
& \text { '... when we were sailing' }
\end{aligned}
$$

[Alozaina (COSER MA3005)]

The generalization of a prepositional marker for all sort of periphrasis could serve as an explanation for the insertion of de in (35) with soler and modal verbs. If so, there would not be necessarily a connection between deismo, which has to be limited to complementation contexts, and this de of periphrastic combinations. 
There are still some other sentences from the same source that may serve as further evidence in this sense. Pato and de Benito Moreno (2012) contains a sentence with the modal verb poder followed by de + infinitive and the clitic le, complement of the infinitive, attached to the first verbal form to the left of $d e$ :

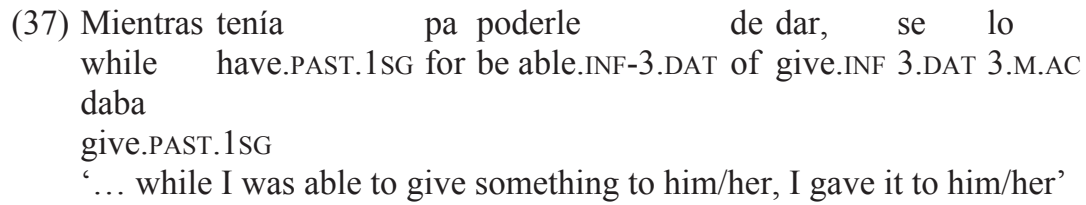

As we have seen before with respect to causative constructions in Ciudad Real, this position for the clitic is not to be expected if de is a complementizer. Otherwise it is perfectly possible for periphrasis in Spanish, where the complements of the non-finite form are often attached to the auxiliary. Our conclusion is then that de in sentences (35)-(37) is to be treated as an extension of a prepositional marker in periphrasis in Andalusia and Extremadura Spanish rather than as examples of de as a complementizer or deísmo.

\subsection{The presence of deísmo in Medieval and Classical Spanish}

As was already mentioned in section 1.2, deísmo has frequently been documented in early Spanish texts in the same contexts where it survives today in substandard speech (Perea Siller 2008; RAE / ASALE 2009: § 43.6u; Di Tullio 2011: 183-185). For instance, a rough inquiry in databases such as CORDE or Davies (2002-) shows how abundant this construction is since medieval times with verbs like pensar, plazer 'to like', probar, prometer, convenir, costar, doler or pesar. Despite it being stigmatized by Juan de Valdés during the first half of the 16th century (Perea Siller 2008: 134), it has been more or less kept until 18th or 19th centuries. Particularly probar and prometer present in Medieval and Classical Spanish even more occurrences with $d e+$ infinitive than without. And, of course, we have also decir de + infinitive since mid 13th century. As we have seen before, all these verbs can still be found among the preferred contexts for deísmo. Other verbs are later incorporated to this list and occur sometimes with deismo in Classical Spanish, a possibility that tends to be less frequent than the one with no complementizer: aceptar 'to accept', dudar 'to doubt', esperar, interesar 'to interest', olvidar 'to forget', prohibir 'to forbid'. It should be pointed out that some of these verbs are not always found in contemporary deismo variants. The examples in (38) below are just an illustrative selection of this type of deismo from 13 th to 17 th centuries: 
(38) a. ... les pesaba de haberlos servido

3.PL.DAT regret.PAST.3SG of have-3.M.PL.AC served

'... they regretted having served them'

[Cervantes Salazar, Crónica (RAE / ASALE 2009: § 43.6u)]

b. Non te conviene de fazer tal cosa que...

not $2 \mathrm{SG}$ be good.PRES.3SG of do.INF such thing that

'It is not good for you to do such a thing ...'

[Bocados de oro, 21, 15, (h. 1250) (CORDE)]

c. ... prometieron de traer la cibdad en poder de los griegos

... promise.PAST.3PL of bring.INF the city in power of the greek

'... they promised to bring the city under the greeks'

[Historia Troyana (c. 1490) (CDavies)]

d. Ca era ya llegado el tiempo que les el that be.PAST.3SG already arrive.PP the time that 3PL.DAT he

dixiera de fazer el tiemplo

say.PAST.3SG of do.INF the temple

'... that the time was arrived for him to tell them to build the temple'

[General Estoria, Cuarta parte, (c. 1280) (CDavies)]

e. ... espero de ser os agradecido algún día.

hope.PRES.1SG of be.INF $2 \mathrm{SG}$ grateful some day

'... I hope to thank you some day'

[El hijo de la cuna de Sevilla (c. 1590) (CDavies)]

Another salient group for ancient deismo was the one formed by the impersonal constructions with ser and an infinitive clause in subject position: ser costumbre / fácil / imposible / lástima / necesario ..., which very often included de preceding the embedded clause:

(39) a. Fea cosa es de soltar el marinero la nave... ugly thing is of release the sailor the boat

'it is an ugly thing for the sailor to release the boat ...'

[Bocados de oro, (RAE / ASALE 2009: § 43.6u)]

b. qu'es plazer de mirarla ...

that-is pleasure of look at.INF-3.F.AC

'... that it is nice to look at it ...'

[Colón, Diario del primer viaje (1492-1493) (CORDE)]

As Perea Siller (2008: 130) reminds us, a group of psychological impersonal verbs already existed in Latin that were clearly related to some of the Spanish verbs just cited. These were accompanied sometimes by a complement in genitive that indicated the cause or origin of the experience. This is precisely what Elvira (2011) clearly refers to in a work dedicated to the medieval expansion in Spanish of this group of Latin verbs. According to him, the argument structure of 
verbs like miseret 'to pity', paenitet 'to regret', piget 'to be annoyed', pudet 'to be ashamed', taedet 'to be tired of', despite disappearing in Romance, provided a pattern that was to be largely adopted at least in Medieval Spanish -with a dative control verb and sentential complement headed by de instead of a genitive-, as (39) shows.

Finally, perception verbs are also found in Old Spanish with an infinitive preceded by $d e$. But the examples are scarce and appear later than some of the structures just mentioned in the preceding paragraphs. They are really unusual with oir 'hear' but not so for the verb ver 'see', particularly in Classical Spanish. Curiously enough, the examples with perception verbs are not at all rare in texts from the last two centuries in the corpus of Davies (2002-). On the other hand, it seems that deismo was not at all available for the causative construction with hacer, neither in Medieval nor in Classical Spanish. Again, the following sentences illustrate this type of structures until 18th century for the verbs of perception:
(40) a. ... que atemoriza
a los que lo oyen
de
that frighten.PRES.3SG to those who 3.M.AC hear.PRES.3PL of llegarse a la oración
arrive.INF-3REFL to the prayer
'.. that frightens those who hear him to pray'
[Teresa de Jesús, Camino de perfección, (1548) (CDavies)]
b. que te uedo de fazer cosas que te touieran pro
that $2 \mathrm{SG}$ see.PRES.1SG of do.INF things that $2 \mathrm{SG}$ have.SUBJ.3PL profit
en tu uida
in your life
'.. that I see you doing things that will be good for your life'
[General Estoria, Cuarta parte, 237r, (c. 1280) CORDE)]

Even though this brief and precarious account of Old Spanish deísmo needs to be developed further, the consideration of the last data and those presented in (38)-(39) apparently suggests that control verbs — and more specifically pseudoimpersonal and impersonal verbs of psychological content - might have been its genuine context. From there it could have expanded to other control environments and finally to the somewhat different structure of 'infinitive with subject in accusative' verbs. That would explain the relative abundance of the former and the scarcity or total absence of the later. Whether or not this is the right explanation, the examination of these historical data shows that deismo in Spanish is not a marginal contemporary innovation, but rather the surviving proof of an ancient alternative complementation pattern for infinitival subordination traced back to even previous Latin models. As Di Tullio (2011: 184) had already claimed, the progress of this construction was abandoned in Spanish in favour of the more frequent pattern with no overt complementizer. 


\section{Deísmo: A Romance pattern of infinitival complementation}

Things, nonetheless, were not the same everywhere in the Romance-speaking areas. The de complementation pattern has survived and is well established in the standard varieties of some other western Romance languages. As Di Tullio (2011: 185) had already claimed, deismo is known in Catalan, French and Italian (Bonet 2002: 2376-2380; Grevisse 1986: §§ 874-876; Kayne 1999; Rizzi 1991: 516-517; Skytte, Salvi and Manzini 1991: 522-527; Egerland and Cennamo 2010: 825-828). It is also documented for Sardinian — with $a$ as complementizer instead of $d e$ - and Occitan (Kayne 1999: 58). The examination of the contexts where it is found in the former three major languages confirms the essential identity between them and Medieval and Classical Spanish pattern of deismo. It mainly appears with all kinds of control verbs preceding an infinitive clause in the position of object or subject, but it is never found with modal verbs. As in Spanish, the presence of a complementizer de seems to be determined by the main control verb, which means that each language has its own list of $d e$ verbs. It includes verbs already cited in relation with Old or Contemporary Spanish deismo: dir / dire / decire 'to say'); probar, intentar / essayer / provare, cercare (di) 'to try'); proposar / proposer / proporre 'to suggest') ... There are also some verbs that select a de infinitive clause in some languages, but not in others. This is the case for the specific versions of Spanish aceptar 'to accept', convenir 'to be advisable', desear 'to want', esperar 'to hope', lamentar 'to regret', ocurrir / pasar 'to happen', pedir 'to ask for', prohibir 'to forbid', prometer 'to promise', recordar 'to remember' (and olvidar 'to forget'), tocar 'to be one's turn' ... It should be pointed out that all of them had been already cited as deísmo triggers either in Medieval and Classical Spanish or in any of the current deísmo varieties. The following sentences illustrate the contemporary Catalan (41), French (42) and Italian (43) uses of some of the verbs mentioned:

(41) a. Proposo de fer-ho tot. suggest.1SG of do.INF-3.N everything

'I suggest to do everything.'

b. Prometo de fer-ho tot. promise.PRES.1SG of do.INF-3.N everything 'I promise to do everything.'

(42) a. J'essaye de tout faire. I try.PRES.1SG of everything do.INF 'I try to do everything.'

b. J'ai oublié de danser. I have.1sG forgotten of dance.INF 'I forgot to dance.'

(43) a. Mi tocca di fare tutto. 3SG be one's turn.PRES.3SG of do.INF everything 'It is my turn to do everything.' 
b. Accetto di fare tutto. accept.PRES.1SG of do.INF everything 'I accept to do everything.'

But there are also some peculiarities and differences in this Romance general complementation procedure. The most significant one is the fact that only in current Spanish deísmo is found in 'infinitive with subject in accusative' structures, that is, in combination with causative and perception verbs. The other diverging behaviour has to do with the distribution of deismo in impersonal structures (like hacer falta and others in Spanish) and those copulative sentences formed by the combination of ser and a nominal or adjectival attribute like ser costumbre / importante / necesario... While this kind of de preceding postverbal infinitive clauses seems to be relatively common in Catalan (44a), it is not found in Italian (44b), where the presence of $d e$ as a complementizer is strongly limited or even forbidden in postand preverbal subject position (Rizzi 1991: 516-517; Kayne 1999):

(44) a. És important de fer-ho ara.

is important of do.INF-3.N now

b. É importante (*di) farlo adesso.

is important of do.INF-3.M. now

'It is important to do it now.'

And, more interestingly, in French the infinitive clauses in this context, while headed by $d e$, co-occur necessarily with an expletive $i l$ as the subject of the copulative verb:

(45) Il est important de le faire maintenant.

it is important of 3.M do.INF now

'It is important to do it now.'

This peculiarity, which is obviously linked to the non pro-drop feature of French, not only shows an important split in the Romance pattern of de complementation, but it also complicates considerably the analysis of $d e$, thus giving way to a certain discussion (Kayne 1999, Borsley 2001).

Nevertheless, from our perspective, the existence of specific traits for each language regarding the extension of deismo does not change the main issue. That is, the early development in Western Romance of a specialized overt complementizer de for non-finite (infinitive) subordination that, despite its limited distribution, parallels the alternative complementizer que in finite subordination. While this complementary distribution between non-finite and finite (overt) complementizers has been preserved until now in the majority of Western Romance languages, it has been moved aside and almost disappeared in contemporary Standard Spanish.

Demonte (2003: 38) introduced for the first time this idea of some kind of division in the way Romance languages introduce subordinate clauses. As we have 
seen, this crucially depends on whether or not they incorporate a Tense feature and can be considered as one of the elements of the considerable microvariation within the area of Romance complementation. Catalan, French or Italian specialized de as the overt complementizer for tenseless declarative clauses. On the other hand, these same languages use only que for tensed sentences including sentences that correspond to PP complements:

\begin{tabular}{|c|c|}
\hline & $\begin{array}{l}\text { M' he ocupat de tot / }\left({ }^{*} \mathrm{de}\right) \text { que tot } \\
\text { 1sG have.1SG been in charge of everything of that everything } \\
\text { estigui preparat. } \\
\text { be.SUBJ.3SG ready } \\
\text { 'I was in charge of everything / I was in charge of having everything } \\
\text { ready.' }\end{array}$ \\
\hline & $\begin{array}{l}\text { Je me suis occupé de tout / }(* \text { de }) \text { que } \\
\text { I 1SG be.PRES.1SG in charge.PP of everything of that } \\
\text { tout soit prêt. } \\
\text { everything be.SUBJ.3SG ready } \\
\text { 'I was in charge of everything / I was in charge of having everything } \\
\text { ready.' }\end{array}$ \\
\hline c. & $\begin{array}{l}\text { Mi fido di te } /(* \text { de }) \text { che sarà } \\
\text { 1SG trust.PRES.1SG of you of that be.FUT.3SG so } \\
\text { 'I trust you / I trust it will be so.' }\end{array}$ \\
\hline
\end{tabular}

Applying the traditional Spanish labels, these languages show not only deismo but also queismo. Let us remember that this was also the pattern followed by Ciudad Real deísmo dialect, where sentences such as those in (46) are exactly paired by a sentence like (20), cited in section 3.2.

On the contrary, in current Standard Spanish the complementizer que does not share with any other form this role. This exclusivity may be the reason behind its compatibility with other forms in that position, for instance in dequeismo or inside PPs. As illustrated before in (3), in Standard Spanish verbs that select a PP as their complement do maintain the preposition, even if the complement is an embedded clause, as opposed to Romance counterparts like (46).

\section{Concluding remarks}

Along these pages we have presented an analysis of a mainly non-standard structure of Contemporary Spanish which consists basically in the insertion of a preposition de before an embedded infinitive clause. After a detailed examination of data from Castilla-La Mancha speech, it has been claimed that this so-called deismo can be considered a case of overt marking of non-finite or tenseless subordinated clauses by means of a new complementizer, de, parallel to the complementizer que for finite clauses. The extension of deismo is limited to some control verbs and appears also in causative constructions and after verbs of perception. It is relatively common 
not only in Castilla-La Mancha Spanish, but also in other Southern Spanish dialects in Extremadura and Andalusia, where it seems to present a wider distribution. But it can also be found sporadically among speakers from many other Spanish-speaking areas, including America.

In fact, deismo is not at all a marginal contemporary innovation, but rather an alternative complementation pattern that was already present in Medieval Spanish. The early and extensive documentation of a complementizer de for infinitival subordination can probably be explained after previous Latin models in psychological impersonal contexts. From there it would eventually be extended to other kinds of control verbs and later to different contexts such as perception and causative verbs.

This hypothesis is reinforced by the consideration of the almost identical facts in neighbouring Romance languages such as Catalan, French or Italian. From their first texts until today standard speech, these languages have incorporated the same complementizer de for infinitive clauses. By doing so, they have finally given way to a complementation system which clearly distinguishes between tensed and tenseless subordinate clauses by means of different complementizers, que and de respectively.

The situation in Spanish seems to have been somehow more confusing. There existed an initial hesitation between whether to insert an overt complementizer de or not to insert any complementizer at all. It survived until at least the 17 th century and finally disappeared in favour of the later solution. Deísmo, then, was confined in Spanish to non-standard or dialectal speech, contrary to what happened in the above-mentioned Romance languages. Something similar, but with a slightly different end, could have happened with respect to complementation in finite clauses considering the current variation that affects the complementizer que and the extension of both queismo and dequeísmo. This same vacillation between que and de $q u e$ is also documented since medieval times, as Serradilla (1995) describes. To sum up, such a scenario of considerable variation may deserve some new scholar interest to past and present Spanish (and Romance) complementation, an area that can still provide new research questions.

\section{References}

Bonet, Sebastià (2002). «Les subordinades substantives». In: Solà, Joan; Lloret, Rosa Maria; Mascaró, Joan; Pérez-Saldanya, Manuel (dirs.). Gramàtica del català contemporani. Barcelona, Empùries, vol. 3, pp. 2321-2387.

Borsley, Robert D. (2001). «What do Prepositional Complementizers do?». Probus 13: $155-171$.

Davies, Mark. (2002-). Corpus del Español: 100 million words, 1200s-1900s (CDavies). Available online at http://www.corpusdelespanol.org.

Demonte, Violeta (2003). «Microvariación sintáctica en español. Rasgos, categorías y virus». In: Álvarez-Santullano, Pilar; Rosas, Minerva; Contreras, Manuel; Jiménez, Pablo (eds.). Texto, Lingüística y Cultura. Osorno: Universidad de Los Lagos / Sociedad Chilena de Lingüística, pp. 9-40. 
Demonte, Violeta; Fernández Soriano, Olga (2001). «'Dequeísmo’ in Spanish and the Structure and Features of CP». In: Herschensohn, Julia; Mallén, Enrique; Zagona, Karen (eds.). Features and Interfaces in Romance. Amsterdam, John Benjamins, pp. 49-70.

Demonte, Violeta; Fernández Soriano, Olga (2005). «Features in Comp and Syntactic Variation: the Case of ‘(de)queísmo' in Spanish». Lingua, 115: 1063-1082.

Demonte, Violeta; Fernández Soriano, Olga (2009). «Force and finiteness in the Spanish complementizer system». Probus 21: 23-49.

Di Tullio, Ángela (2011). «Infinitivos introducidos por de». Cuadernos de la ALFAL 3: 176-187.

Egerland, Verner; Cennamo, Michela (2010). «Frasi subordinate all’infinito». In: Salvi, Giampaolo; Renzi, Lorenzo (eds.). Grammatica dell'italiano antico. Bologna: Il Mulino, vol. II, pp. 817-879.

Elvira, Javier (2011). «Constructions of uncontrolled state or event. The increase in productivity of a new argument structure in Old Spanish». Constructions and frames 3: 184-207.

Fernández Ordóñez, Inés (dir.) (2005-). Corpus oral y sonoro del español rural (COSER). Universidad Autónoma de Madrid. http://www.uam.es/coser/.

García Fernández, Luis (dir.) (2006). Diccionario de perífrasis verbales. Madrid: Gredos.

García Mouton, Pilar; Moreno Fernández, Francisco (2003). Atlas lingüístico y etnográfico de Castilla-La Mancha (ALECMan). http://www.linguas.net/alecman/.

Gómez Torrego, Leonardo (1999). «La variación en las subordinadas sustantivas: Dequeísmo y queísmo». In: Bosque, Ignacio; Demonte, Violeta (dirs.). Gramática descriptiva de la lengua española. Madrid, Espasa Calpe, pp. 2105-2148.

Grevisse, Maurice (1986). Le bon usage. Paris-Gembloux: Duculot [12ème édition].

Hernanz, M. Lluïsa (1999). «El infinitivo». In: Bosque, Ignacio; Demonte, Violeta (dirs.). Gramática descriptiva de la lengua española. Madrid, Espasa Calpe, pp. 2197-2356.

Kayne, Richard S. (1999). «Prepositional Complementizers as Attractors». Probus 11: 39-73.

Llorente Maldonado, Antonio (1980). «Consideraciones sobre el español actual». Anuario de Letras 18: 5-61.

Moral, Gabriel del (2008). «Spanish dequeísmo a case study of subjectification». Nueva Revista de Lenguas Extranjeras 10: 183-214.

Náñez, Emilio (1984). «Sobre dequeísmo». Revista de Filología Románica 2: 239-248.

Pato, Enrique; de Benito Moreno, Carlota (2012). «Sobre el infinitivo con de en castellano meridional». Edisyn Workshop on Ibero-Romance Dialects: Clitics and Beyond. Getafe: Universidad Carlos III.

Perea Siller, Francisco J. (2008). «Deísmo, queísmo y dequeísmo: entre la variación y los cambios lingüísticos». ED.UCO. Revista de investigación educativa 3 : 117-142.

RAE / ASALE (2009). Nueva gramática de la lengua española. Madrid, Espasa Calpe.

RAE. Corpus diacrónico del español (CORDE). http://corpus.rae.es/cordenet.html.

Rizzi, Luigi (1991). «Il sintagma preposizionale». In: Renzi, Lorenzo; Salvi, Giampaolo; Cardinaletti, Ana Maria (eds.). Grande grammatica italiana di consultazione. Il Mulino, Bologna, vol. I, pp. 507-531. 
Serradilla, Ana $M^{a}$ (1995). «Sobre las primeras apariciones de construcciones preposicionales ante "que" completivo en español medieval: factores determinantes». Epos 11: 147-164.

Skytte, Gunver; Salvi, Giampaolo; Manzini, M. Rita (1991). «Frasi subordinate all'infinito». In: Renzi, Lorenzo; Salvi, Giampaolo; Cardinaletti, Ana Maria (eds). Grande grammatica italiana di consultazione. Il Mulino, Bologna, vol. II, pp. 497-569.

Zamora Vicente, Alonso (1970). Dialectología española. Madrid: Gredos. 
